OPEN ACCESS

Edited by: Carol Kerven

University College London,

United Kingdom

Reviewed by:

Rashmi Singh,

Ambedkar University Delhi, India

Suman Aryal,

University of Southern

Queensland, Australia

${ }^{*}$ Correspondence:

Kuenga Namgay

kuengadruk@gmail.com

Specialty section:

This article was submitted to Agroecology and Ecosystem Services, a section of the journal Frontiers in Sustainable Food Systems

Received: 16 October 2020

Accepted: 04 January 2021

Published: 18 February 2021

Citation:

Namgay K, Millar JE and Black RS

(2021) The Future of Transhumants'

Sustainable Resource Use in Bhutan:

Pressures and Policies.

Front. Sustain. Food Syst. 5:618351.

doi: 10.3389/fsufs.2021.618351

\section{The Future of Transhumants' Sustainable Resource Use in Bhutan: Pressures and Policies}

\author{
Kuenga Namgay ${ }^{1,2 *}$, Joanne E. Millar ${ }^{2}$ and Rosemary S. Black ${ }^{2}$ \\ ${ }^{1}$ Department of Livestock, Ministry of Agriculture and Forests, Thimphu, Bhutan, ${ }^{2}$ Institute of Land Water and Society, \\ Charles Sturt University, Albury, NSW, Australia
}

Cattle and yaks in Bhutan are mainly managed in a transhumance system, grazing common pooled resources. This is, however, changing due mainly to policy changes and development pressure. The unequal land policies now restrict mobility for cattlebased transhumance by agro-pastoralists although it is expected to remain the same for the yak-based pastoralists. Essential public infrastructures also are being built in the common pooled resources, thus reducing the grazing areas for cattle and yaks alike. This study uses qualitative interview and focus group discussions in conjunction with administrative data and policy documents to understand the forces that increasingly lead to the decline of transhumance and see how it might change the grazing landscape and socialscape in the future. The study finds that grazing in the future will likely transform from an extensive to a semi-intensive system with smaller herd sizes for cattle-based agropastoralists. This is being achieved through interventions implemented by the livestock department, promoting crossbreeding with European dairy breeds. Transhumant herder turned sedentary smallholder farmers are fast adopting a sedentary lifestyle. This is changing not only the landscapes from grazing in large expanses of forest and open meadows to restricted semi-intensively managed smallholder farms with a possible impact on biodiversity. Crossbreds of European dairy cattle are fast replacing indigenous siri cattle of the Bos indicus type. Yak-based transhumance is expected to continue with favorable policies and other opportunities, including collection of the highly priced caterpillar fungus, Cordyceps sinensis. The socialscapes are fast changing for both highlanders as well as mid and lowland herders. Many of these places inhabited by herders are now connected by motorable roads, shortening their travel time to the nearest health facilities or shops from days to hours.

Keywords: transhumance, mobility, adaptation, sedentarization, cattle, yaks

\section{INTRODUCTION}

Today, pastoralists globally, are faced with myriad challenges and opportunities arising from economic development, social change, climate change, conservation, and sedentarization policies, population growth, and war or conflicts (Behnke, 1983; Ellis and Swift, 1988; Fratkin et al., 2004; Nori and Davies, 2007; Galvin, 2009). Some of these challenges can have a catastrophic impact on pastoralists' livelihood either temporarily or long-lasting (Moritz, 2008; Scoones, 2008). It 
can constrain them from employing their adaptive strategies and deny them support for their sustainable development. As a consequence, pastoralists today are moving into the twenty first century with less ability to maintain their subsistence livestock economies than at any time in the past (Bonte et al., 1996; Fratkin, 1997; Ning and Richard, 1999).

In Bhutan, traditionally, cattle and yaks were both grazed in extensive systems, many often practicing mobile pastoralism. Local breeds of cattle called nublang, a Bos indicus type of Himalayan cattle breed and its crossbreds with Mithun (Bos frontalis) formed the dominant livestock breeds. The nublang cows are often crossbred with Mithun for better milk production, higher butterfat content, and superior draft performance. These breeds thrived well in this extensive system with minimal supplementary feeding. The only supplementary feeding farmers provided to milking cows were semiboiled turnip and radishes with the stems or maize flour and rice bran. In essence, these mobile pastoralists in Bhutan, as is the case anywhere in the world, utilize dry, poor-quality land that is often unsuitable for conventional agriculture and ephemeral resources and convert to food products such as milk, butter, cheese, meat, and hide. Because transhumance in Bhutan is based on the local cattle, mobile herders are the custodians of the cattle genetic resources, conserving the indigenous cattle breeds thus far (Namgay et al., 2014).

Further, it is evident that people created the range-landscapes they used for grazing their cattle and yaks. As landscapes are "the result of the action and interaction of natural and/or human factors" (ELC, 2000), rangelands in Bhutan are shaped by man for human and livestock use. It is plausible to claim Bhutanese pastoralists created the rangelands in Bhutan and mobile pastoralism formed the primary vocation of early Bhutanese. These are shaped by clearing and burning out undergrowth, a critical management practice for sustainable grass production. For example, Ura (2002) writes,

Alpine rangelands in Merak, above 3,900 meters, were created several hundred years ago; according to its settlement history, the name Merak means "settlement created by burning out."

Similarly, rangelands in Tibet are claimed to be created by people through bush clearance as opposed to nature given (Miehe et al., 2009). Pastoralism and the nature of rangeland creation in Nepal have also been described in a similar fashion (Goldstein, 1974; Macfarlane, 1989; Banjade and Paudel, 2009). Mobile pastoralism was widespread and thrived in Asia's rangelands including the Himalayan ranges, for thousands of years. Pastoralism and transhumance in these regions occur in areas that are remote and forested and in open highlands, unsuitable for cropping, moving in tandem with forage availability and temperature shifts (Miller, 1995; Singh et al., 2013). Recent evidence suggests pastoralism in Tibet started some 8,000 years ago during the mid-Holocene climatic optimum (Miehe et al., 2009).

This literature evidence suggests that cattle herding with transhumance as the predominant system perhaps formed one of the primary vocations of earlier Bhutanese people. It is possible that the transhumant alpine yak system and cattlebased transhumant agro-pastoralism not only formed the oldest production sectors, but also happened to be the sector early theocratic and initial monarchic governance systems relied on for maintenance of the state system. It was not until other agricultural and non-agricultural alternatives became possible that people could establish more sedentarized lifestyles.

However, such systems are increasingly coming to an end amid many changes, including climate and policy. With the introduction of development plans in the 1960s, government subsidy schemes promoted crossbreeding of local cattle with European breeds, encouraging sedentary farming systems. This was done to increase both productivity per animal and overall milk production. Until 1998, a breed barrier was established such that jersey crosses were promoted in warm temperate to subtropic areas and brown Swiss cattle were promoted in cold temperate places. Since then, by popular demand from farmers, the breed barrier was removed, and jerseys became popular throughout the country. The state-owned farms breed these exotic cattle and supply breeding materials, mostly bulls, to farmers for crossbreeding with local cattle. In recent years, the government started procuring and promoting the use of sexed semen in farmer fields as well as government central farms to increase the crossbred female population.

The government policies on access to these resources consistently discouraged cattle-based interdistrict transhumance. The latest such policy is the Land Act of Bhutan (2007), which set 2018 as the definite year for cessation of interdistrict cattle migration (Namgay et al., 2017). The dominant policy narrative in Bhutan is that local cattle are low yielding, use large tracts of pasture as well as forest, and cause forest degradation; therefore, they need to be reduced or replaced with high-yielding exotic breeds that require smaller spaces and have higher milk yield.

These policies have a huge impact on the way the livestock are now raised and how rangelands and socialscapes are changing or likely to change. This study, therefore, examines the pressures and challenges mobile pastoralism face as a result of these changes and tries to comprehend how this might change the grazing landscape and socialscape in Bhutan among mobile pastoralists.

\section{THEORETICAL FRAMEWORK: PASTORAL ADAPTATION}

Today, the literature on adaptation is overwhelmingly associated with climate change and its effect on ecosystems and society and closely linked with resilience and vulnerability (Kates, 2000; Smit and Wandel, 2006; Nelson et al., 2007; Jerneck and Olsson, 2008).

Smith and Wandel (2006, p. 282) define adaptation in the context of human dimensions of global change as follows:

\footnotetext{
"... a process, action or outcome in a system (household, community, group, sector, region, country) in order for the system to better cope with, manage or adjust to some changing conditions, stress, hazard, risk or opportunity."
} 
Adaptation can, therefore, be defined as balancing between livelihood capitals within the space provided by ecosystems, tenure institutions, climatic conditions, and alternative economic opportunities to maintain a constant supply of goods and services to the actor units. In other words, it is an effort to survive or advance through smart management of internal factors of production in constant interaction with external factors based on informed decisions. Adaptation is a dynamic process occurring at differential scales, spatially and temporally, necessitating flexibility in the system to respond to changes and reduce negative impacts (Smit and Wandel, 2006; Galvin, 2009). Adaptation enhances system resilience and reduces vulnerability (Smit and Wandel, 2006; Nelson et al., 2007; Jerneck and Olsson, 2008).

Pastoralists, in general, are constantly adapting through seasonal migration, manipulation of herd size, sedentarization, commercialization, diversification, and adoption of alternative lifestyles wherever feasible, including emigration to urban areas (Niamir-Fuller, 2005; Smit and Wandel, 2006; Galvin, 2009).

\section{Pastoralists' Adaptation Strategies}

Pastoralists' adaptation strategies include seasonal transhumance (mobility), commercialization, sedentarization, diversification, and adoption of alternative livelihood options similar to their cropping farmer counterparts (Ellis, 1998, 2000). The changes or stressors impact adaptability differentially, affecting the poorer sections of the society the most. Pastoralists, with limited livelihood capitals, who depend heavily on natural resources, are often forced to abandon their livelihood as a consequence of these changes (Kates, 2000; Intigrinova, 2005; Niamir-Fuller, 2005; Nori and Davies, 2007; Pachauri, 2007), resulting in further marginalization. Some adaptation interventions, brought about by agencies, conflict with the acquisition of adaptive capacity of the poor and result in increased vulnerability and, hence, expel them away from their livelihood source altogether (NiamirFuller, 1999; Kates, 2000).

\section{Diversification as an Adaptation Strategy}

Pastoralists diversify their livelihood options, including sedentarization in peri-urban areas, to tap available opportunities. Some men, after settling near peri-urban areas, continue to keep pastoral cattle while women adopt additional trades in the urban market (Watson, 2010).

Adoption of diversification can both be a desperate coping strategy for the rural poor or spread income streams by wealthy households (Ellis, 1996; Start, 2001). Ellis (2000) calls it "diversification of necessity and diversification by choice." The majority of rural households practice diversification and engage in a range of livelihood portfolios because income from their main farming occupation alone is not enough to sustain the household. Often, income from other sources is much higher compared with income from their primary livelihood (Ellis, 1999). The existence of inter- and intra-community heterogeneity in well-being levels and, hence, a need to adapt through diversification is not always due to a lack of livelihood assets or capitals, but due to the absence of equitable access or entitlement to vital resources (Sen, 1982; De Haan, 2000; Davies and Bennett, 2007).

Pastoralists sometimes move into non-pastoral trades, often with total abandonment of pastoralism (Start, 2001; Smit and Wandel, 2006; Davies and Bennett, 2007; Galvin, 2009). For example, many Himalayan pastoralists have diversified and are now engaged in agriculture, trade, and tourism. Some integrate animal husbandry with agriculture. In an integrated system, livestock provide milk, butter, cheese, meat, and valuable inputs needed for crops, such as manure to maintain soil fertility and draft power to plow fields as well as pack animals for transportation during transhumance or for tourism services (Miller, 1995; McVeigh, 2004).

\section{Sedentarization and Commercialization as an Adaptation}

Sedentarization and settling, especially in peri-urban areas, is generally perceived to potentially enhance human capital through improved access to health care and educational opportunities. Sedentarization, either through government policies or of their own will, is a growing trend but has mixed impacts, particularly on pastoral women (Watson, 2010). In some African pastoral societies, although married couples may diversify with men continuing to go with animals leaving women to collect firewood or grow vegetables, female-headed households are likely to suffer further marginalization as a result of biased social norms that look down upon women with no husbands (Watson, 2010). In these societies, commercialization can have negative impacts on women and increases their vulnerability as the trend follows that, as herd sizes grow beyond a subsistence level, the economy of the herd becomes more of a business orientation and comes more under the control of men than women (Watson, 2010).

\section{MATERIALS AND METHODS}

\section{Study Area}

This study explored the changing grazing landscapes and socialscapes as a consequence of a multitude of policies and pressures in Bhutan. Bhutan is a small and mountainous country with a total geographical area of $38,394 \mathrm{~km}^{2}$ (NSB (National Statistical Bureau), 2018). The country's landscape is dominated by mountain ecosystems and changes within a distance of $170 \mathrm{~km}$ from elevations of about $100 \mathrm{~m}$ in the foothills to more than $7,500 \mathrm{~m}$ above sea level. The country is largely agrarian with more than $69 \%$ of the population living in rural areas, relying primarily on agriculture. With as many as $80 \%$ of the members of the poor households engaged in agriculture, livestock plays a key role in shaping and strengthening their livelihoods. With little grown fodder, Bhutanese farmers depend extensively on crop residues and forest resources for cattle grazing and fodder collection.

The renewable natural resources (RNR) sector, comprising agriculture, livestock, and forestry sectors, together contributed around $15.89 \%$ to the gross domestic product (GDP) in 2019. Of these, the agriculture sector contributed $8.43 \%$, followed by livestock and forestry sectors at 4.46 and 3.0\%, respectively (DoL (Department of Livestock), 2020). 


\section{Data Collection and Analysis}

This paper used some unpublished qualitative data collected earlier for a $\mathrm{PhD}$ research project. This is supplemented by administrative data, review of government office reports, policy documents, acts and rules, and other relevant literature.

The study administrative data and factors identified cover the whole of the country where transhumant mobile pastoralism and grazing in common pooled resources (CPR) are commonly practiced.

A total of 33 interviews (25 male participants, 8 female participants) and 3 focus group discussions were conducted with herders, experts, government officials, and local government authorities. The 33 interview participants comprised 24 migrating households and nine experts. They are now experiencing changes both in the policies and their influence on herding practices. The nine experts (six government and three non-government) were chosen based on their knowledge and experience in livestock development and environmental policies in Bhutan. The focus group discussions with 64 participants (40 male, 24 female) were also held to collect feedback and seek consensus among a wider audience on emerging issues highlighted during the interviews, such as factors contributing to the decline of local cattle, policy changes, and their adaptation strategies.

Purposive and snowballing methods were used to identify participants with prior experience in transhumant pastoralism and who understand the emerging issues (Noy, 2008). The snowballing technique is most commonly used in interdisciplinary qualitative social science research, wherein a key informant refers the researcher to others based on their knowledge (Noy, 2008).

All the interviews with herder informants and focus group discussions were conducted face to face in the national language: Dzongkha. Interviews with open-ended questions formed the core tool for this research in exploring herders' experiences and in eliciting issues (Tong et al., 2007).

All interviews and focus group discussions were recorded with a digital recorder and later transcribed and translated into English. Data analysis comprised coding, categorization, and thematization (Charmaz and Bryant, 2008).

The results are presented as a composite of excerpts from interviews and focus group discussions, a literature review, government department administrative data, and a critical review of policy and plan documents.

\section{RESULTS}

\section{The Declining Trend in Indigenous Cattle Population as a Consequence of Development Policies}

The following section provides the current scenario of the changing breed composition of cattle and the reasons that are the precursor to such trends. The interviews revealed changes to the cattle breeds and quality of the herd over the years. Most of the herders stated the overall herd composition of migratory herds have changed from herds being largely of Nublang (Bos indicus) and Jatshams [crossbred between pure Mithun (Bos frontalis)] to now include exotic breeds, such as jerseys, brown Swiss, and Holstein crosses.

The interview statements are substantiated by the cattle population trend over the years as shown in the graph in Figure 1. The overall cattle population has seen only a half a percentage point $(0.50 \%)$ rise between the years 1994 and 2018, due mainly to the rise in the exotic cattle population. During the same period, the exotic cattle population increased manifold (269.54\%) from 29,981 in 1994 to 116,733 numbers in 2018. However, the indigenous cattle population has decreased by more than a quarter $(-29.40 \%)$ within 24 years. The exotic crossbred cattle are fast replacing indigenous breeds of cattle as a result of government policies and promotional programs favoring exotic as opposed to indigenous cattle breeds.

However, the same cannot be implied for yak population trends. Amid many fluctuations over the years, the yak population has, rather, increased by around 13\% during the same period (Figure 2). The yaks do not have competing breeds of choice unlike the cattle. Although inter-regional differences exist in the quality of the yaks, due mainly to level of inbreeding and genetic degeneration, the breeds are not significantly different between yak-rearing districts in Bhutan.

These trends are a consequence of policies including the livestock breeding policy (more on this policy can be found in subsequent sections) that is seen as biased and grossly discriminatory against the indigenous breeds Nublang and Jatsha-Jatsham. Herders under the transhumance system seem to prefer local breeds for their hardiness-a crucial quality necessary for migration, good butterfat content, easy management, and good draft power usage. However, they are responding to policies and government programs and are now increasingly adopting exotic crossbreds suitable in sedentary farming systems.

\section{Pressures on the Grazing Resources Competition From Alternative Development Uses}

Land competition from development and commercial agriculture, public infrastructure, systems change, a labor shortage, and youth and outmigration of men are contributing to the decline in pastoralism from the way it used to be.

Grazing resources used by transhumant agro-pastoralists, commonly held as $\mathrm{CPR}$, including rangelands, today have come under immense pressure from competing uses. Rangelands continue to shrink in the name of development and are changing as a consequence of policies. Much public infrastructure is built in the rangelands, inter alia, local government offices, community centers, agriculture and livestock extension offices, forest range and park offices, gates, schools, village banks, and farm shops.

Additionally, today an increasing number of households are getting into contractual plantation of hazelnut plants with the Mountain Hazelnut ventures company. These areas previously formed some of the main grazing areas for cattle in the locality. The company website (www.mountainhazelnuts.com) indicates some 15,000 households setting up hazelnut orchards in areas that would be used for grazing their cattle. 


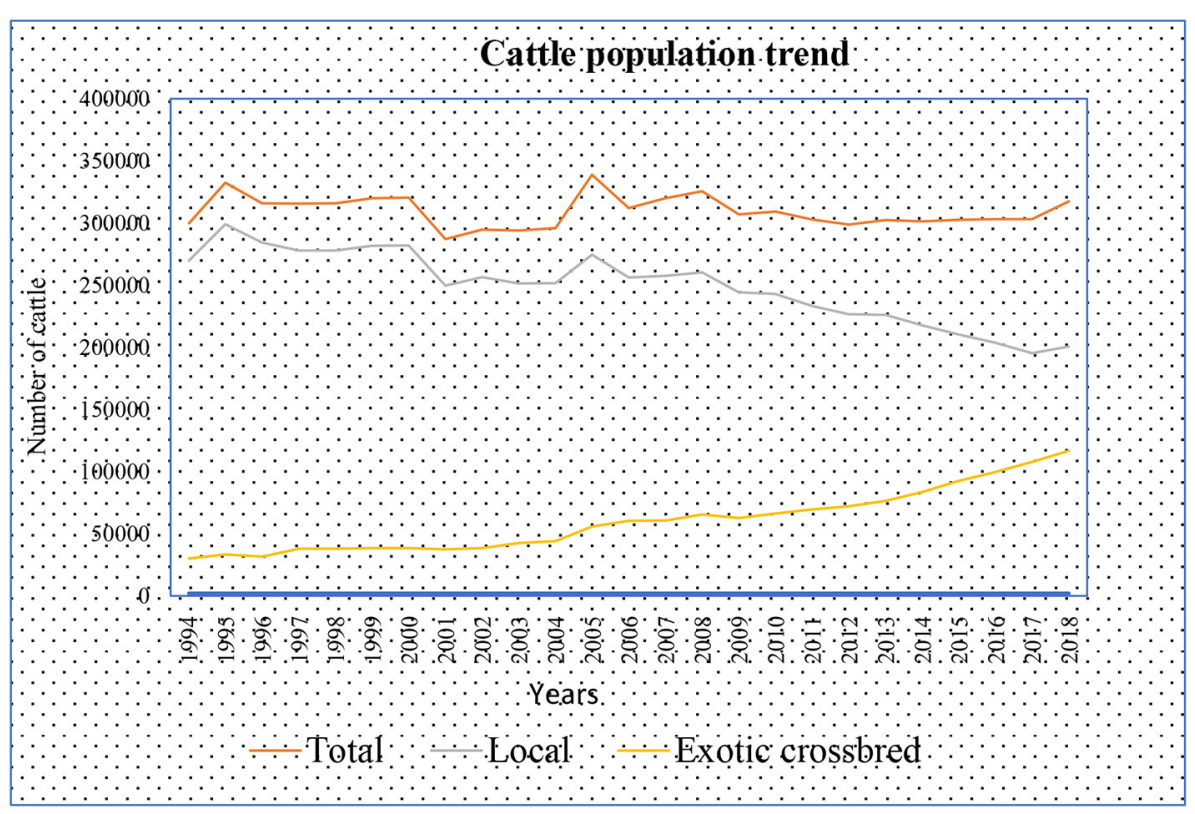

FIGURE 1 | Cattle population change.

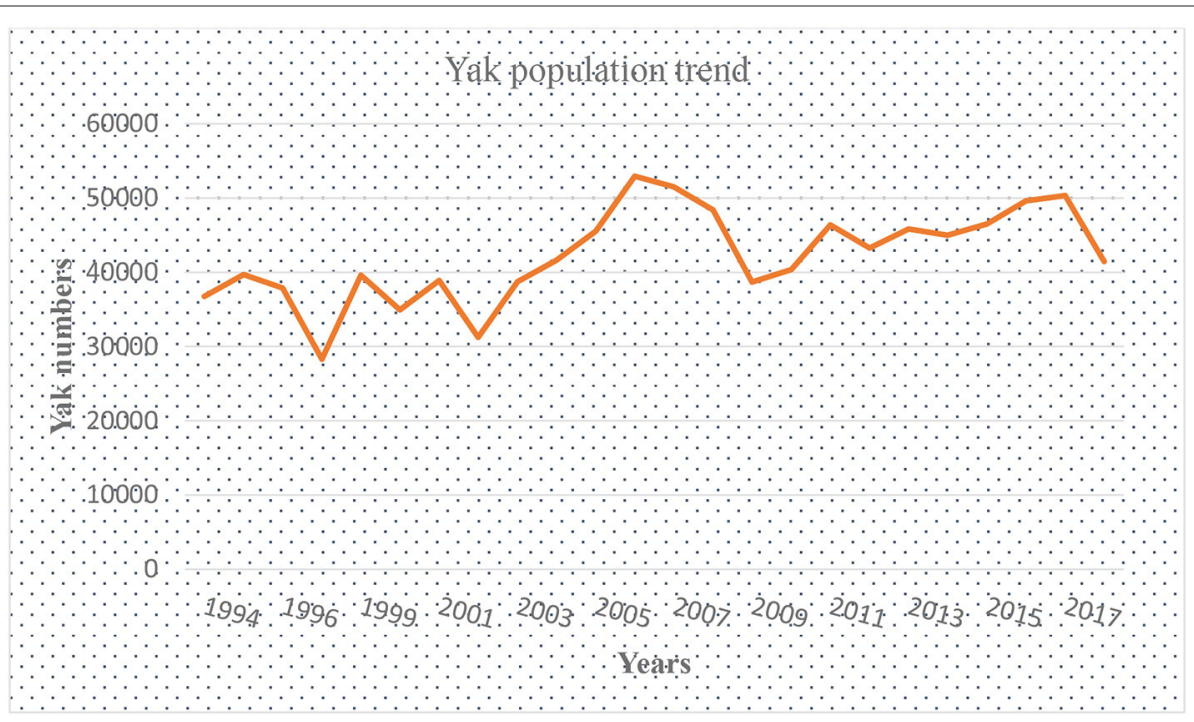

FIGURE 2 | Yak population trend.

\section{Transformation in Transport System}

With modern development, power tillers and tractors were introduced for tilling agricultural land. Construction of roads and farm roads into the villages took away the roles played by oxen for plowing and transporting goods during seasonal transhumant migration. Although usage of tractors is limited owing to the topography in large parts of the country, power tillers are gaining popularity. Many of the horses used by the pastoralists in carrying their household items during seasonal migration and later for transporting oranges to fetch cash have now been rendered redundant except for a few who are now engaged in transporting tourists and their logistics to camp sites. Many of these horses have now turned semi-feral.

Government initiatives with support from the Government of Japan have afforded a supply of farm machines at subsidized rates. In 2020, there were a total of 4,550 power tillers and some 30 tractors in Bhutan with the farmers and government hiring agency [Agriculture Machinery Center (AMC), personal communication and self-calculation], and there were only 16,820 horses [DoL (Department of Livestock), 2019] many of which lay unused. 


\section{Policies and Legislation Restricting Transhumance and Forest Grazing}

Institutional reforms have transformed private, joint, and common grazing areas into state lands and imposed several restrictions on areas commonly used for grazing by transhumant pastoralists.

According to two agency experts, tsamdro (local term for grazing land or pasture) titling accorded during the premonarch era (before 1907) and later under monarchic rules were subsequently reflected in the national land records. This is said to have happened when the national assembly in 1953 accorded full private ownership rights of tsamdros to individual and joint ownership, similar to other land categories. However, the first land law of the country - the Land Act of Bhutan of 1979in the words of one agency expert, "diluted the ownership of tsamdros" and put an end to tax collection. Hence, instead of tax collection, only permit/lease fees were collected, indicating the nationalization of tsamdros, converting herders' tsamdro ownership rights to mere usufructuary rights.

One herder key informant who lived through these changes explains how these changes took place:

“...earlier it was tax, then it was permit with a fee of about Ngultrum [term for Bhutanese currency] 100...It was Ngultrum 100 per annum per household irrespective of the size of tsamdro, either big or small, as long as it is registered as tsamdro in your name." (Herder_33)

Another male herder reiterated the same and explained that, since 2008, the government has also stopped collecting the $\mathrm{Nu}$. 100 permit fee:

“... we have been paying taxes and fees, but it has been now three years, gewog [local government] office did not collect that either. Until that time we have been paying and getting the receipt." (Herder_27)

This was an indication that the tsamdros have once again been nationalized under the new land law (Land Act 2007).

The following section describes different laws and policies that have relevance and how each of these has impacted the transhumant pastoralism in Bhutan.

\section{Forest Act of 1969}

One of the first legislations in Bhutan, the Forest Act of 1969, restricts cattle grazing only in the reserved forest and allows it in other forest areas with fees.

This law, however, banned the use of fire, which has resulted in the spread of rhododendron shrubs overtaking what was once open rangelands and has reduced grazing areas. Traditional rangeland management practices meant clearing these bushes and burning them to allow grasses to grow. Herders burnt bamboo and rhododendron shrubs periodically to create space for the regrowth of other species. Such periodic burning is described as "brogshed" by Ura (2002) and the undergrowth in chirpine forest was regularly cleared by fire. The Yardrog rangelands of Merak in northeastern Bhutan benefitted from such burning because the fire promoted the growth of fresh bamboo shoots and grasses (Chophyel, 2009).

In other areas, losing grazing areas to pine forest and a consequent reduction in grazing areas resonated strongly among herder participants during the focus group discussions. The participants believed that restrictions by the forest department on clearing bushes and burning has resulted in pine trees invading their prime grazing areas. The participants said that no grasses grow under the pine trees.

A male participant in his sixties said the following:

Earlier we use to clear the camp sites and grazing areas by cutting and burning the bushes. Now because of the forest restrictions saying its environment, trees are important and, not allowed to do this or clear that; these trees are taking over even our agricultural fields.

The same point was mentioned during another focus group discussion. Many herder participants believe the restriction by the forest department on their traditional pasture management practices is converting their good pastures to pine forests.

A male participant in his fifties said the following:

Well, earlier... as soon as the herd reaches here, we clear some of the bushes and burn them, so we used to have huge open areas for cattle to graze. Now, because we are not allowed to cut or burn the bushes, the pine trees take over the open areas and there is nothing under those trees to graze.

This trend was evident from the researcher's observation in all the study areas. Many areas in and around their villages, which the village elders indicated had been used for growing buckwheat in the past, are now all covered in thick pine forests. Most pine trees in the village premises are still young, meaning these are not old forests but new growth in what used to be agricultural fields, grown after the ban on slash-and-burn practices came into effect.

\section{Forest Policy of 1974}

The first written policy in Bhutan is the forest policy of 1974. One of the principles in the earliest forest management practices, inter alia, is to meet the requirement of forage for cattle. However, the policy notes that grazing rights being with the local people is damaging the soil, vegetation cover, and forest regeneration process. Therefore, the policy foresees acquisition of such rights by the government and allowing controlled grazing through payment of taxes.

\section{Draft Pasture Policy of 1985}

The draft pasture policy of 1985, although never formalized, is being practiced in vogue. Among many other interventions, such as developing pasture with exotic fodder species, the draft pasture policy, right in the objective mentions nationalizing grazing rights and redistributing them through leases of 30 years at a stretch. The policy puts a cap on the extent of pastureland a household can lease based on the livestock units it holds. The policy, however, does not mention putting restrictions on interdistrict transhumance movement. Apparently, the policy 
draws its inspiration from the Land Act of Bhutan of 1979 (RGoB (Royal Government of Bhutan), 1985).

\section{Forest and Nature Conservation Act of 1995}

Article 30, sections A-C, indicates permitting regulated grazing in government-reserved forests with penalties or seizure if trespassing into areas closed to grazing.

\section{Forest Policy of 2008}

Although the policy states that Bhutan's forest should benefit its people and mentions poverty alleviation a couple of times, save for ensuring subsidized rural timber, there is no specific mention of how the forest would benefit grazing or livestock keepers. The only mention of livestock is, in highlighting the importance for watershed management, it purports watersheds' pivotal role in supplying a wide range of goods and services for, among others, pastoral pursuits and in sustaining the livelihoods of upland farmers and grazers.

\section{Department of Livestock's 12th Five Year Plan (12FYP)}

The current livestock development plan also is biased toward exotic breeds over local breeds; thus, all allied services are also directed toward crossbreeding and conventional/modern semi-intensive/intensive farming systems. The overall budget for development of livestock in the 12FYP (2018-2023) is BTN 904 million ( USD 12.9 million). The bulk of this development budget is meant for improving livestock breeds, including cattle; improving nutrition and health; and providing a subsidy on building improved housing. Although there is a separate budget of BTN 317 million ( USD 4.5 million), equivalent to $35 \%$ of the total plan outlay, specifically for a highland development program targeted at yak herders, there is no specific mention of a budget for mobile pastoral cattle. The remaining budget is meant for improving breeds, nutrition, health, research, and development services of all the other livestock species, including cattle, in a conventional way [DoL (Department of Livestock), 2019].

\section{Draft Livestock Policy}

The draft livestock policy of Bhutan of 2012 only recognizes the existence of transhumant systems in the preamble and does not make a single mention in the subsequent main texts (MoAF (Ministry of Agriculture and Forests), 2012).

The policy, de facto, promotes crossbreeding of most livestock and poultry species with exotic breeds to increase production. Exotic cattle breeds, especially jersey, are preferred over local indigenous cattle: Nublang, a siri cattle of the Bos indicus type. Jersey crossbreds are, however, not suitable for long-distance travel on foot-necessary for transhumance.

The government development plan mentions increasing the crossbreds [DoL (Department of Livestock), 2019]. All technical and fiscal incentives are directed at increasing the population of the exotic breeds over local breeds (MoAF (Ministry of Agriculture and Forests), 2019).

Increasingly, government efforts are being made to enable sedentarized farmers to take advantage of modern technologies and farm inputs. Breeding materials, such as jersey bulls and imported semen, conventional as well as sexed, are being distributed free of cost to communities. Other subsidies, including the cost of materials for constructing improved sheds and silo pits and integration with the bio-gas system, are subsidized by the government. Improved fodder seeds are distributed, encouraging establishment of grown pastures as opposed to grazing in open meadows or forest. In the 12FYP (2018-2023) government targets are to establish about 26,614.00 acres of improved pasture and winter fodder [DoL (Department of Livestock), 2019].

The trend is also to encourage farmers to form groups, cooperatives, and federations. Many of the government subsidies are targeted to groups and less to individuals. In 2018, there were 347 farmer groups and 57 cooperatives, including 582 semicommercial and 361 commercial-scale livestock farms. Women represent $20 \%$ and $18 \%$ in membership and leadership roles, respectively (Namgay, 2017).

\section{Livestock Act of 2001}

The livestock act (2001) mentions standards to be followed in breeding and operation of farms with restrictions to prevent incursion of diseases. Except for the need to follow certain rules to contain/prevent disease spread, the act does not make any mention of whether transhumant pastoralism is discouraged (RGoB (Royal Government of Bhutan), 2001).

\section{Land Policy of Bhutan of 2007}

The land policy of Bhutan (2010) provides for leasing of state reserved forest (SRF) land for agriculture and livestock production. It does not specify whether a proponent from a different district leases SRF for transhumant pastoralism (NLCS (National Land Commission Secretariat), 2010).

\section{Land Act of Bhutan of 2007}

Chapter 10, article 235, of this act mentions deleting all tsamdro (grazing land) rights from the thram (land title document) and reverting the land back to the government if it is in an urban area or to government reserved forest land if in the rural areas. Further, article 236 states that the reverted tsamdro in rural areas shall be converted to leasehold, and that in thromde shall remain as government land. Article 240 provides for the leasing of reverted tsamdro to individuals or communities owning livestock with preference being given to previous rights holders. Article 247 requires that grazing and pasture development on tsamdro be permitted based on a management plan with the department of forests, the department of livestock, and the lessee responsible for its preparation.

The Land Act of Bhutan of 2007 is one of the earliest forms of legislation that sets a definite time within which the grazing rights held by livestock keepers, including transhumant herders, are to be nationalized. The law sets 2018 as the year within which the nationalization should happen (RGoB (Royal Government of Bhutan), 2007). It further states that subsequent leasehold rights shall only be granted to residents domiciled in a particular district, barring transhumant pastoralists who traditionally moved between two or more districts seasonally. 
Section 239 of the Land Act of Bhutan of 2007 states the following:

After 10 years from the date of enactment of this Act, Tsamdro shall be leased only to a lessee who is a resident of the Dzongkhag where the Tsamdro is situated.

\section{National Biodiversity Strategies and Action Plan Bhutan (NBSAP) of 2014}

The NBSAP identifies overgrazing as one of the direct pressures among the threats affecting biodiversity.

\section{Forest and Nature Conservation Rules (Amendment) of 2020}

The amended Forest and Nature Conservation Rules (2020) make no mention of grazing or transhumance use for livestock production except for classifying the type of lands and restrictions for lands provided by the National Land Commission for purposes including lease (MoAF (Ministry of Agriculture and Forests), 2020).

\section{DISCUSSION}

\section{Declining Indigenous Cattle and Transhumant System as a Consequence of Development and Policy Reforms}

The persistent forest protection and environment conservation policies and legislation in Bhutan have steadily tightened access to forest grazing resources. The dominant narratives of the effect of cattle on the environment have influenced the livestock development approach, restricting mobility with a preference for a more intensive way of livestock farming. Restrictions on traditional management practices, such as bush clearing and burning, have resulted in grazing pastures being overtaken by unpalatable bushes, thus reducing effective grazing areas and increasing pressure on limited rangeland areas suitable for grazing. Lessons from the neighboring countries in the region indicate adverse impacts on both vegetation and livelihood in the alpine ecosystem as a consequence of restrictive environmental rules (Nautiyal and Kaechele, 2007).

Despite the fact that pastoralism is a finely adapted production system, suited to highly variable environmental conditions, thus presenting potential compatibility with wildlife conservation, production is highly compromised owing to reduced access to grazing resources, civil unrest, and climate change (Gerber et al., 2010).

The dominant view among policy makers of developing nations that local people are to blame for environmental degradation is a perceived notion rather than evidence-based (Leach and Mearns, 1996). Their view developed through Western education, and supported and reinforced by donor agencies, influences the image of the environment and the urgency to protect areas for conservation. These exaggerations of environmental degradation, supposedly caused by the herders and local people's access to natural resources, have become a common belief among some foresters and environmental agencies (Chambers, 1997). These crisis narratives have helped develop frames and shape the mindset of some policy makers (Leach and Mearns, 1996).

Recent reviews reveal the outcomes of livestock grazing on forest are mixed, indicating benefits as well as the effects of forest grazing. The much cited reason, overgrazing, in conservation documents in Bhutan, even if there is a certain degree of truth, cannot solely be blamed on grazing by cattle. Grazing overlap and competition with wild ungulates are also reported in Bhutan (Gyamtsho, 2000).

Consequently, grazing areas, including rangelands, that were managed by transhumant herders with planned herding and controlled burning, thus mimicking nature and making livelihoods out of ephemeral resources, are likely to be converted to wilderness. This could possibly lead to deterioration of the social fabric, customs, and indigenous rules and regulations governing these grazing rangelands (Herrera et al., 2014).

With the emerging political ecology, aside from the dominant proconservation discourses, there is often no scientific data on the extent of degradation or the main reasons causing degradation (Leach and Mearns, 1996; Chambers, 1997). However, there are repeated portrayals of pastoralists and rural people (especially ones located between state-created protected and conservation areas) as agents of environmental destruction in public discourse through media and policy discussion circles that has changed the frame of public perception (Lakoff, 2004; Brower, 2008). These trends, which Lakoff calls "ignoring the fact and accepting the frame," have led to an increase in the number of protected and conservation areas in developing countries, resulting in an upsurge in wildlife populations, causing increased incidences of human-wildlife conflicts, leaving the rural populace, including TAP herders, worse off (Blench, 2005).

The creation of protected areas, conservation areas, and biosphere reserves has resulted in reduction in grazing areas in the Indian Himalayas as well, thereby increasing stocking density per unit areas (Nautiyal et al., 2003). Competition and exclusion through enclosures has also occurred in Ladakh, where military enclosures have reduced grazing areas and caused an increase in stocking density per unit areas (Namgail et al., 2007).

This attenuation of pastoralists' grazing resources is further exacerbated by land grabs by national commercial cropping firms and foreign ownership of land by capital-rich nations with governments of poor nations giving concessions to attract investment (Cribb, 2010; Robertson and Pinstrup-Andersen, 2010; Zoomers, 2010). This trend is likely to have food security implications for the marginalized groups, including pastoralists (Robertson and Pinstrup-Andersen, 2010; Zoomers, 2010).

\section{Converting Transhumant Herds Into Semi-intensive, Stall-Fed Farms, and Changing Grazing Landscape and Socialscape}

Pastoralists in general and particularly in Africa are politically marginalized on top of being poverty-stricken and vulnerable to livelihood shocks (Eneyew, 2012). However, transhumant pastoralists in Bhutan are a bit different. Although, owing to geoclimatic conditions, agriculture-based livelihood choices 
are limited, there is no obvious political marginalization. No categorization of citizens into minority or indigenous groups or political dominance exists in Bhutan. Citizens enjoy equal status as a Bhutanese, irrespective of their ethnicity or livelihood choices.

Although grazing by pastoral animals in the forests has several benefits, in terms of biodiversity conservation, reduced soil erosion and increased soil quality, improved air and water quality, better plant diversity, increased level of control on exotic (weedy) grasses, adding manure to the nutrient cycle, and seed dispersal, pastoralists face a number of issues accessing rangelands, and states increasingly encourage them to sedentarize in Lebanon (Sarkis et al., 2019).

Rangelands, home to herders, grazed by livestock and wildlife, and defined predominately as grasslands, are undergoing unprecedented changes worldwide. These grazing resources are being converted to urban centers and farms to satisfy the growing need of burgeoning human populations. Changing consumer preferences demands a shift from a traditional subsistence system to more market-orientated commercial production. The changing system, however, questions economic as well as environmental sustainability (Galvin et al., 2016).

The government policy in Bhutan encourages the raising of exotic cattle breeds with stall-feeding practices aimed at improving the income of rural folks, including those transhumant pastoralists. However, the overriding narrative is different than is implied in the African continent. Although ease of governance, provision of services, and improving the quality of life of pastoralists are dominant reasons for settling them in Africa (Eneyew, 2012), in Bhutan, they are blamed for keeping large herds thought to be detrimental to the environment. No scientific evidence exists as yet that proves overgrazing by pastoralists keeping local cattle with larger herd sizes causes environmental damage. These policies draw on broad narratives applied globally to mobile pastoralism wherein they are blamed for keeping large herds supposedly causing overgrazing, deforestation, etc. (Fratkin and Mearns, 2003).

Bhutanese transhumant agro-pastoralists are fast adapting to the changes. Although yak herders, favored by the law (RGoB (Royal Government of Bhutan), 2007), albeit a declining trend, continue the traditional transhumance practice, cattlebased agro-pastoralists have almost abandoned mobility and have settled in their permanent residencies. Transhumant agropastoralists have not only lost the opportunity to graze in subtropical tsamdros but also any opportunity to engage in orange business during the winter months (Namgay et al., 2014). They now increasing adopt stall-feeding or local grazing with exotic crossbreds and are increasingly engaged in vegetable production. Although climate change is a major global concern with livestock systems as both the cause and victim as is the case in many developing countries (Thornton et al., 2009), there is no sufficient data or literature to make any claim either way in Bhutan. It is, however, clear that exotic crossbred cattle will replace the native cattle breeds substantially. Unless conservation efforts are strengthened, a well-adapted and resilient breed such as Nublang cattle appears likely to disappear.
Although pastoralists in central Asia use the off-farm income of family members to buy more animals and increase their flock size (Kerven et al., 2011), in Bhutan, the off-farm income of family members are being used to buy improved cattle and settle out of transhumance practice. However, similarities in ownership of pasturelands exists between central Asian agropastoralists and Bhutanese transhumant agro-pastoralists. They never had ownership of the pastureland de facto. Although Bhutanese pastoralists have had pasturelands registered in their names, which they thought was ownership, the true ownership, de jure, always rested with the state and was held in usufructuary rights.

A similar decline in pastoralists' mobility and their increasingly adopting sedentary farming were observed in Kazakhstan for various reasons. It is also noted that flocks that did not practice seasonal movement had to graze in the overgrazed pasture in the locality and were poorer in growth and production (Kerven et al., 2004).

In the face of rising demand for dairy products and meat and climate change effects, pastoralists, the custodians of indigenous, locally adapted cattle breeds, should be supported. Supporting sustainable pastoralism suited to local environments would contribute to seven of the 17 sustainable development goals (SDGs); SDG 1: No poverty, SDG 2: Zero hunger, SDG 3: Good health and well-being, SDG 8: Decent work and economic growth, SDG 12: Responsible consumption and production, SDG 13: Climate action, and SDG 15: Life on land (FAO, 2020).

Scoones and Nori (2020) draw a parallel between how nations are having to adapt in the face of the current global Covid-19 pandemic with how pastoralists have always adapted under uncertain environment, climate, and policy conditions. Pastoralists, by virtue of living in a disequilibrium environment, having to triangulate various sources of knowledge and advice from experts, modern and traditional, to make the most reliable decisions in the face of uncertainty, resemble the current situation of governments around the world dealing with the uncertainty of the Covid-19 outbreak (Scoones and Nori, 2020). This teaches leaders a lesson, something that nations could learn from each other's experience and perhaps learn from pastoralists experience of adapting and living with uncertainty. However, because the cattle-based transhumant agro-pastoralists are now losing their adaptation tools or tactics, most importantly mobility, it is not certain how well they will adapt to variabilities, inter alia, market and climate.

The current efforts of technical departments in Bhutan are in line with Kristjanson et al. (2010), focusing on the three main areas to enhancing productivity of smallholder livestock keepers: feeds, breeds, and health. More attention now needs to be paid to other interventions, such as improving croplivestock interactions in mixed smallholder farms, livestock water productivity, carbon sequestration on rangelands, and efficiency of farm animal labor, to harness the ability to increase the productivity of these smallholders (Kristjanson et al., 2010).

This multitude of factors and changing policies and climate necessitate transhumant agro-pastoralists to adapt quickly. This 
is not only going to transform the grazing landscape, but also the socialscapes - the way communities interact and play roles in society. Grazing landscapes will change from grazing in community pastures, open rangelands, and meadows to being tethered or grazed in the homestead-grown pasture or stall fed. The older practice and social fabric of neighbors grazing cattle in communal pastures, singing, and playing together will likely disappear. As much as the government expects them to work in groups and cooperatives, many of these induced institutions do not succeed in maintaining the traditional communal bonds and community vitality. The households would now be more individualistic, aiming to increase their production and generate more money. However, with limited land holding and poor feeding management practices now compounded by a labor shortage, it is not clear how settled pastoralists would be able to capitalize on sedentary farming with an exotic crossbred livestock and market economy.

In traditional pastoral societies, men own more cattle than women (Kristjanson et al., 2010). This is understandable when implied in the Bhutanese context, as in the pastoral system, herders need to stay in faraway places in the forest, often having to climb trees to lop fodder for young stock in the camp. This places women in a disadvantaged position compared with men. This is not so when they change and adapt to intensive/semi-intensive systems. These latter farms are near the homestead, using improved grasses, and expected to give a higher yield. These farms, when integrated with bio-gas systems, not only save labor by avoiding having to go to the forest and climb trees, but also sequester carbon and manage GHG more efficiently. The GHG from manure is trapped and used in the kitchen for cooking purposes. Integrating farms with bio-gas systems also save on fuel wood and other household energy expenditure. Because these farms are closer to the villages, this provides for a level playing field for women.

Transhumance is necessitated by seasonal environmental variability and resource availability. The practice resonates with that of rotational grazing, thus avoiding overgrazing (Aryal et al., 2018). In places where there is better temporal distribution of moisture and suitable temperature favoring year-round pasture growth, sedentary farming is recommendable. Himalayan high mountain areas are cold, dry, and frost-bitten during the winter months, posing a challenge to sedentary farming. Therefore, without proper housing and conserved forage, the condition and productivity of animals will diminish drastically during winter months. Advocacy, education, and training vis-à-vis interventions will need to be promoted on proper housing and fodder conservation during summer to give proper protection and nutrition in winter months.

It may not warrant the all out closure of transhumant movement and expecting every herder to adopt a sedentary lifestyle. An inclusive participatory process could have afforded choices to households to either adopt a sedentary lifestyle or continue with transhumance. The shortage of labor is already forcing some households to abandon transhumant movement and adopt sedentary farming. Political decentralization, proper coordination, and inclusive participatory discourse would result in more equitable distribution and sustainable management of rangeland resources and livelihood choices (Herrera et al., 2014).

Although the policies and interventions are intended in good faith, it is not clear how uniformly every pastoralist household would adopt and take advantage of the government subsidies. Given that the subsidies are uniform as opposed to the spatial heterogeneity in the households' response system owing to the variability in the capitals, how well every pastoralist household adopts it is yet to be proven (Thornton et al., 2009). What is perhaps of importance is to assist the pastoralists with marketing of their products. Government and international agency interventions in building capacity of the pastoralists in sustainable livestock management, value chain management, and marketing would result in higher income for pastoralists and better outcome to the environment as a result of improved management practices (Kerven, 2010).

As much as there are commonalities between sedentary agrarian farming and pastoralism (including transhumant production systems), there are key differences in both their social relations and productive forces (Scoones, 2020). Perhaps because most professionals and policy makers come with background on settled agriculture from universities and lack in-depth understanding of transhumant pastoral production systems, policies and interventions always target discrediting their practices.

\section{CONCLUSION}

Bhutanese transhumant agro-pastoralists are adjusting to changes brought about by development and environmental conservation policies. This is changing both grazing landscapes and socialscapes. Many of the erstwhile tsamdros would likely turn into wilderness although some would be leased by residents domiciled in particular districts as pastureland. A majority of the transhumant agro-pastoralists have already sedentarized, and others would soon follow suit. This would change the whole social fabric with new outlook and approach toward cattle raising. Many of them would now raise exotic cattle and get into milk groups and/or cooperatives.

Although this may have seemingly had a negative impact economically on those who have had access to larger grazing areas and not faced labor shortages, for others, these developments are coming in handy. Many rural communities have faced acute labor shortages with children being in school and/or having adopted an urban lifestyle. Bhutanese rural communities are turning youthless and toothless. It is becoming increasingly difficult to find people to go after the animals. As villages run short of farm labor, youth with some schooling are emigrating out of villages into the towns, looking for jobs and, thus, contributing to unemployment statistics. This is a concern for the government to reform the education system to incorporate more vocational learning into the system to make young people employable and create employment opportunities. 
On other hand, within the limitations of topography and fragmented land holdings, agriculture in Bhutan has to transform toward more use of technology to make it easy and attractive to youth.

Adopting a sedentary system would also improve children's attendance at school. In the past, some children cut short their school attendance to accompany their parents while migrating south with their cattle. As a result, some children do not get to study beyond primary schooling.

5 Yak herders are also facing the challenges of labor shortages, reduced grazing areas and climate change impacts. However, they continue to hang on because of favorable government policies as well as the incentive of collecting caterpillar fungus, Cordyceps sinensis, worth more than 1,000 USD per kilogram. However, the distribution of such caterpillar fungus is not uniform in all highlands. Therefore, the wellbeing of yak-based pastoralists when such incentives are absent has to be considered, and opportunities need to be created.

\section{REFERENCES}

Aryal, S., Maraseni, T., Cockfield, G., and de Bruyn, L. L. (2018). “Transhumance, livestock mobility and mutual benefits between crop and livestock production," in Sustainable Agriculture Reviews 31. Sustainable Agriculture Reviews, Vol. 31, ed E. Lichtfouse (Cham: Springer), 25-39.

Banjade, M. R., and Paudel, N. S. (2009). Mobile pastoralism in crisis: challenges, conflicts and status of pasture tenure in Nepal mountains. J. For. Livelihood 7:49.

Behnke, R. H. (1983). Production rationales: the commercialization of subsistence pastoralism. Nomad. People 14, 3-34.

Blench, R. M. (2005). Livestock Predation in Central Bhutan: The Impacts of Social and Economic Change. Work in Progress. ODI. Cambridge Retrieved from: http://www.rogerblench.info/Anthropology data/Text/Bhutan predators.pdf

Bonte, P., Guillaume, H., and Zecchin, F. (1996). Nomads: changing societies and environments. Nat. Resour. UNESCO Q. J. Environ. Nat. Resour. Res. 32, 2-10.

Brower, A. (2008). Who Owns the High Country. The Controversial Story of Tenure Review in New Zealand (Nelson: Potton \& Burton), 70-71.

Chambers, R. (1997). Whose Reality Counts?: Putting the First Last. London: Intermediate Technology Publications.

Charmaz, K., and Bryant, A. (2008). "Ground theory research: Methods and practices," in: The Sage Handbook of Grounded Theory, eds K. Charmaz and A. Bryant (London: Sage Publications), 1-28.

Chophyel, P. (2009). Rangeland Management in Bhutan Consultancy Report. Thimphu: Ministry of Agriculture, Royal Government of Bhutan.

Cribb, J. (2010). The Coming Famine: The Global Food Crisis and What We Can Do to Avoid It. Collingwood, VIC: CSIRO.

Davies, J., and Bennett, R. (2007). Livelihood adaptation to risk: constraints and opportunities for pastoral development in Ethiopia's Afar region. J. Dev. Stud. 43, 490-511. doi: 10.1080/002203807012 04422

De Haan, L. J. (2000). Globalization, localization and sustainable livelihood. Sociol. Ruralis 40, 339-365. doi: 10.1111/1467-9523.00152

DoL (Department of Livestock) (2019). Twelfth Five Year Plan (2018 - 2023). Achieving Livestock Product Self-Sufficiency for a Prosperous and Self-Reliant Society Living in Harmony With Nature. Ministry of Agriculture and Forests, Royal Government of Bhutan.

DoL (Department of Livestock) (2020). Annual Report 2019 - 2020. Department of Livestock, Ministry of Agriculture and Forests, Royal Government of Bhutan.

ELC (2000). European Landscape Convention. Article 1a.

Ellis, F. (1996). Rural Livelihood Diversity in Developing Countries: Evidence and Policy Implications. EMBRAPA-CPAF Amapa.

\section{DATA AVAILABILITY STATEMENT}

The original contributions presented in the study are included in the article/supplementary material, further inquiries can be directed to the corresponding author/s.

\section{ETHICS STATEMENT}

The studies involving human participants were reviewed and approved by the Charles Sturt University Human Research Ethics Committee. The participants provided their written informed consent to participate in this study.

\section{AUTHOR CONTRIBUTIONS}

KN did data collection, analysis and write up. JM and RB supervised the research, contributed in design and structure of the article, and coedited the manuscript. All authors contributed to this article and approved the submitted version.

Ellis, F. (1998). Household strategies and rural livelihood diversification. J. Dev. Stud. 35, 1-38. doi: 10.1080/00220389808422553

Ellis, F. (1999). Rural livelihood diversity in developing countries: Evidence and policy implications Natural Resource Perspectives (Vol. 40): Overseas Development Institute (ODI).

Ellis, F. (2000). The determinants of rural livelihood diversification in developing countries. J. Agric. Econ. 51, 289-302. doi: 10.1111/j.1477-9552.2000.tb01229.x

Ellis, J. E., and Swift, D. M. (1988). Stability of African pastoral ecosystems: alternate paradigms and implications for development. J. Range Manage. 41, 450-459. doi: $10.2307 / 3899515$

Eneyew, A. (2012). Is settling pastoralists a viable livelihood strategy? Implication for policy dialogue. Scholarly J. Agric. Sci. 2, 94-102.

FAO (2020). Innovative Pastoralism: Achieving Productivity and Sustainability for Food Security. Available online at: www.fao.org/3/cb1185en/CB1185EN.pdf

Fratkin, E. (1997). Pastoralism: governance and development issues. Annu. Rev. Anthropol. 26, 235-261. doi: 10.1146/annurev.anthro.26.1.235

Fratkin, E., and Mearns, R. (2003). Sustainability and pastoral livelihoods: lessons from East African Maasai and Mongolia. Hum. Organ. 62, 112-122. doi: 10.17730/humo.62.2.am1qpp36eqgxh3h1

Fratkin, E., Roth, E. A., and Nathan, M. A. (2004). Pastoral sedentarization and its effects on children's diet, health, and growth among Rendille of Northern Kenya. Hum. Ecol. 32, 531-559. doi: 10.1007/s10745-004-6096-8

Galvin, K. A. (2009). Transitions: pastoralists living with change. Annu. Rev. Anthropol. 38, 185-198. doi: 10.1146/annurev-anthro-091908-164442

Galvin, K. A., Reid, R. S., Ferna n dez-Gime nez, M. E., Kaelo, D. Baival, B, and Krebs, M. (2016). Co-design of transformative research for rangeland sustainability. Curr. Opin. Environ. Sustain. 20, 8-14. doi: 10.1016/j.cosust.2016.03.003

Gerber, P., Mooney, H., and Dijkman, J. (2010). Livestock in a Changing Landscape: Experiences and Regional Perspectives, Vol. 2. Washington, DC: Island Pr.

Goldstein, M. (1974). Tibetan speaking agro-pastoralists of Limi: a cultural ecological overview of high altitude adaptation in the Northwest Himalaya. Objets et Mondes 14, 259-286.

Gyamtsho, P. (2000). Economy of yak herders. J. Bhutan Stud. 2, 86-127.

Herrera, P. M., Davies, J. M., and Baena, P. M. (2014). The Governance of Rangelands; Collective Action for Sustainable Pastoralism. Introduction. Routledge.

Intigrinova, T. (2005). Transhumance in transition: consequences of socioeconomic reform. A case study of Khoito Gol, Buryatia. Inner Asia 7, 87-105. doi: 10.1163/146481705793646982

Jerneck, A., and Olsson, L. (2008). Adaptation and the poor: development, resilience and transition. Clim. Policy 8, 170-182. doi: 10.3763/cpol.2007.0434 
Kates, R. W. (2000). Cautionary tales: adaptation and the global poor. Clim. Change 45, 5-17. doi: 10.1023/A:1005672413880

Kerven, C. (2010). "New opportunities for improving livelihoods by marketing livestock products from Alay and Pamirs of Kyrgyzstan and Tajikistan: high value cashmere from indigenous goats," in Regional Workshop in Khorog and Kashgar Edition of Workshop Resolution: Pastoralism and Rangeland Management in Mountain Areas in the Context of Climate and Global Change, eds H. Kreutzmann, K. Abdulalishoev, L. Zhaohui, J. Richter (Bonn).

Kerven, C., Alimaev, I. I., Behnke, R., Davidson, G., Franchois, L., Malmakov, N., et al. (2004). Retraction and expansion of flock mobility in central Asia: costs and consequences. Afr. J. Range Forage Sci. 21, 91-102. doi: 10.2989/10220110409485848

Kerven, C., Steimann, B., Ashley, L., Dear, C., and Rahim, I. (2011). "Pastoralism and farming in Central Asia's mountains: a research review." MSRC Background Paper No. 1 September 2011. Available online at: http://www.ucentralasia.org/ downloads/pastoralism_and_farming_in_central_asia_mountains

Kristjanson, P., Waters-Bayer, A., Johnson, N., Tipilda, A., Njuki, J., Baltenweck, I., et al. (2010). "Livestock and women's livelihoods: a review of the recent evidence," Discussion Paper No. 20 (Nairobi: ILRI).

Lakoff, G. (2004). Don't Think of an Elephant: Know Your Values and Frame the Debate, Vermont: Chelsea Green Publishing.

Leach, M., and Mearns, R. (1996). "Environmental change and policy," in The Lie of the Land. Challenging Received Wisdom on the African Environment, eds M. Leach and R. Mearns (Oxford: James Currey), 1-33.

Macfarlane, A. (1989). Some background notes on Gurung identity in a period of rapid change. Kailash 15, 179-190.

McVeigh, C. (2004). Himalayan herding is alive and well: the economics of pastoralism in the Langtang valley. Nomad. People 8, 107-124. doi: 10.3167/082279404780446023

Miehe, G., Miehe, S., Kaiser, K., Reudenbach, C., Behrendes, L., and Schlütz, F. (2009). How old is pastoralism in Tibet? An ecological approach to the making of a Tibetan landscape. Palaeogeogr. Palaeoclimatol. Palaeoecol. 276, 130-147. doi: $10.1016 /$ j.palaeo.2009.03.005

Miller, D. (1995). "Herds on the move: winds of change among pastoralists in the Himalayas and on the Tibetan Plateau," in Discussion Paper MNR 95/2 (Kathmandu: ICIMOD).

MoAF (Ministry of Agriculture and Forests) (2012). Draft National Livestock Sector Development Policy of the Kingdom of Bhutan. Royal Government of Bhutan.

MoAF (Ministry of Agriculture and Forests) (2019). Guidelines on Cost Sharing Mechanism for RNR Sector for the 12th FYP. Royal Government of Bhutan.

MoAF (Ministry of Agriculture and Forests) (2020). Forest and Nature Conservation (Amendment) Rules and Regulations of Bhutan. Department of Forests. Royal Government of Bhutan.

Moritz, M. (2008). Competing paradigms in pastoral development? A perspective from the Far North of Cameroon. World Devt. 36, 2243-2254. doi: 10.1016/j.worlddev.2007.10.015

Namgail, T., Bhatnagar, Y. V., Mishra, C., and Bagchi, S. (2007). Pastoral nomads of the Indian Changthang: production system, landuse and socioeconomic changes. Hum. Ecol. 35, 497-504. doi: 10.1007/s10745-006-9107-0

Namgay, K. (2017). Women Farmers in Bhutan. South - South Cooperation Forum in South Asia: Promoting Sustainable Family Farming Agriculture to Achieve SDG1 and 2. Organized by Asian Farmers Association for Sustainable Rural Development (AFA), United Nations Food and Agriculture Organization (FAO), and with the facilitation of the South Asia Association for Regional Cooperation (SAARC) through its secretariat and the SAARC Agriculture Center (SAC), Kathmandu, Nepal.

Namgay, K., Millar, J. E., and Black, R. S. (2017). Dynamics of grazing policy and its impact on migratory herders in Bhutan. Rangeland Jo. 39, 97-104. doi: 10.1071/RJ16052

Namgay, K., Millar, J. E., Black, R. S., and Samdup, T. (2014). Changes in transhumant agro-pastoralism in Bhutan: a disappearing livelihood? Hum. Ecol. 42, 779-792. doi: 10.1007/s10745-014-9684-2

Nautiyal, S., and Kaechele, H. (2007). Adverse impacts of pasture abandonment in Himalayan protected areas: testing the efficiency of a natural resource management plan (NRMP). Environ. Impact Assess. Rev. 27, 109-125. doi: 10.1016/j.eiar.2006.10.003

Nautiyal, S., Rao, K. S., Maikhuri, R. K., and Saxena, K. G. (2003). Transhumant pastoralism in the Nanda Devi Biosphere Reserve,
India: a case study in the buffer zone. Mt. Res. Dev. 23, 255-262. doi: 10.1659/0276-4741(2003)023[0255:TPITND]2.0.CO;2

Nelson, D. R., Adger, W. N., and Brown, K. (2007). Adaptation to environmental change: contributions of a resilience framework. Annu. Rev. Environ. Resour. 32, 395-419. doi: 10.1146/annurev.energy.32.051807.09 0348

Niamir-Fuller, M. (1999). "Managing mobility in African rangelands," in Paper Presented at the Property Rights, Risk, and Livestock Development in Africa (Feldafing).

Niamir-Fuller, M. (2005). Managing Mobility in African Rangelands. Collective Action and Property Rights for Sustainable Rangeland Management. Washington, DC: CAPRI. doi: 10.3362/9781780442 761.000

Ning, W., and Richard, C. E. (1999). "The privatisation process of rangeland and its impacts on the pastoral dynamics in the Hindu Kush Himalaya: the case of Western Sichuan, China," Paper Presented at the 6th International Rangeland Congress (Townsville, QLD).

NLCS (National Land Commission Secretariat) (2010). The National Land Policy of Bhutan. Royal Government of Bhutan.

Nori, M., and Davies, J. (2007). Change of Wind or Wind of Change? Climate Change, Adaptation and Pastoralism. Nairobi: WISP, IUCN.

Noy, C. (2008). Sampling knowledge: the hermeneutics of snowball sampling in qualitative research. Int. J. Soc. Res. Methodol. 11, 327-344. doi: 10.1080/13645570701401305

NSB (National Statistical Bureau) (2018). Statistical Year Book of Bhutan 2018. Thimphu: Royal Government of Bhutan.

Pachauri, R. K. (2007). Climate Change 2007: Synthesis Report. Contribution of Working Groups I, II and III to the Fourth Assessment Report of the Intergovernmental Panel on Climate Change, Vol. 446. IPCC.

RGoB (Royal Government of Bhutan) (1985). Draft Pasture Policy-March 1985. Animal Husbandry Department. Ministry of Agriculture and Forestry.

RGoB (Royal Government of Bhutan) (2001). Livestock Act of Bhutan 2001. Ministry of Agriculture.

RGoB (Royal Government of Bhutan) (2007). The Land Act of Bhutan 2007.

Robertson, B., and Pinstrup-Andersen, P. (2010). Global land acquisition: neo-colonialism or development opportunity? Food Secur. 2, 271-283. doi: 10.1007/s12571-010-0068-1

Sarkis, L., Hamzeh, J., and Engin, Y. (2019). "Mobile pastoralism in shouf (Lebanon)," in Mobile Pastoralism in Mediterranean Landscapes: The State of (mobile) Pastoralism in Five Pilot Sites, ed E. A. Yilmaz (Yolda Initiative publication).

Scoones, I. (2008). Is Pastoralism a Viable Livelihood Option? id21 Insights: Research Findings for Development Policy Makers and Practitioners, 72. Retrieved from: http://www.eldis.org/id21ext/publications/insights72.pdf (accessed November 2012).

Scoones, I. (2020). Pastoralists and peasants: perspectives on agrarian change. J. Peasant Stud. 1-47. doi: 10.1080/03066150.2020.1802249

Scoones, I., and Nori, M. (2020). Living With Coronavirus Uncertainties: Four Lessons From Pastoralists. PASTRES: Pastoralism, Uncertainty, Resilience. Available online at: https://pastres.org/2020/03/27/living-with-coronavirusfour-lessons-from-pastoralists/?utm_campaign=New at IDS\%7C COVID-19 updates\%7C (accessed April 8, 2020).

Sen, A. (1982). Poverty and Famines: An Essay on Entitlement and Deprivation. New York, NY: Oxford University Press.

Singh, N., Bhatnagar, Y. V., Lecomte, N., Fox, J. L., and Yoccoz, N. G. (2013). No longer tracking greenery in high altitudes: pastoral practices of Rupshu nomads and their implications for biodiversity conservation. Pastoral. Res. Policy Pract. 3:16. doi: 10.1186/2041-7136-3-16

Smit, B., and Wandel, J. (2006). Adaptation, adaptive capacity and vulnerability. Glob. Environ. Change 16, 282-292. doi: 10.1016/j.gloenvcha.2006. 03.008

Start, D. (2001). The rise and fall of the rural non-farm economy: poverty impacts and policy options. Dev. Policy Rev. 19, 491-505. doi: 10.1111/1467-7679. 00147

Thornton, P. K., van de Steeg, J., Notenbaert, A., and Herrero, M. (2009). The impact of climate change on livestock and livestock systems in developing countries: a review of what we know and what we need to know. Agric. Syst 10, 113-127. doi: 10.1016/j.agsy.2009.05.002 
Tong, A., Sainsbury, P., and Craig, J. (2007). Consolidated criteria for reporting qualitative research (COREQ): a 32-item checklist for interviews and focus groups. Int. J. Q. Health Care 19, 349-357. doi: 10.1093/intqhe/ mzm042

Ura, K. (2002). The herdsmen's dilemma. J. Bhutan Stud. 7, 1-43.

Watson, C. (2010). Gender Issues and Pastoral Economic Growth and Development in Ethiopia Background Note for a Study of "Pastoral Economic Growth and Development in Ethiopia". Adis Ababa: DFID and Government of Ethiopia.

Zoomers, A. (2010). Globalisation and the foreignisation of space: seven processes driving the current global land grab. J. Peasant Stud. 37, 429-447. doi: $10.1080 / 03066151003595325$
Conflict of Interest: The authors declare that the research was conducted in the absence of any commercial or financial relationships that could be construed as a potential conflict of interest.

Copyright (c) 2021 Namgay, Millar and Black. This is an open-access article distributed under the terms of the Creative Commons Attribution License (CC BY). The use, distribution or reproduction in other forums is permitted, provided the original author(s) and the copyright owner(s) are credited and that the original publication in this journal is cited, in accordance with accepted academic practice. No use, distribution or reproduction is permitted which does not comply with these terms. 